\title{
2: $158500579-158418469$
}

National Cancer Institute

\section{Source}

National Cancer Institute. 2: 158500579-158418469. NCI Thesaurus. Code C41643.

Physical location of ACVR1_Gene 